\title{
Monitoring Agricultural Expansion during the Economic Crisis in Indonesia: A Case Study of the Rawa Danau Nature Reserve
}

\author{
Arief Darmawan $^{* 1, * 3}$, Lilik Budi Prasetyo*2 and Satoshi Tsuyuki*1
}

\begin{abstract}
Following the 1997 Indonesian economic crisis, faith in agriculture was justified and plantation farmers reacted by expanding their fields at the expense of forest cover. The objectives of this study were to examine the spatial pattern of land-cover changes that occurred in the Rawa Danau Nature Reserve, Indonesia, with the background of the economic crisis period and to characterize the situation of local people causing agricultural expansion in this area. A satellite-image analysis and a household-survey analysis were executed. The economic crisis has played a major role in changing land-use practices and has affected protected areas. The satellite-image analysis shows that a rapid change of vegetation-cover occurred after the economic crisis as compared with the period prior to the crisis. The household-survey and spatial analyses show that, initially, villagers located near protected areas are more likely to encroach on protected areas than villagers located further away from protected areas. However, after a period of several years, even distant villagers encroached upon the nature reserve. Aside from proximity of access, the smaller size of agricultural land holdings, the larger number of tenant farmers and the increase of unmonitored access to the nature reserve after the economic crisis were the characteristics of agricultural expansion villages within the study area.
\end{abstract}

Keywords: land-cover change, agricultural expansion, economic crisis, satellite-image analysis, household-survey analysis

\section{INTRODUCTION}

Land-use and land-cover change (LULCC) can be a major threat to biodiversity through the destruction of the natural vegetation and the fragmentation or isolation of nature areas (VERBURG et al., 2006). Both regional and local-scale studies have demonstrated a number of critical events that give rise to land-cover change, such as tropical deforestation (GEIST and LAmbin, 2002; Kummer and Turner, 1994; Verburg et al., 2006). In particular, agricultural expansion is the leading landuse change associated with nearly all global deforestation cases (GEIST and LAMBIN, 2002).
According to BOSERUP (1965), there are two general types of agricultural systems: extensive agriculture and intensive agriculture. Extensive agriculture tends to exist where there is relatively low population pressure, together with widely available land resources and simple technological systems (lower input). In contrast, intensive agriculture occurs in high densely populated regions with limited land resources, accompanied by evolution in agricultural technique (higher input) due to frequent cropping.

Limited land resource problems occur in two situations either when the opportunity to obtain new land is severely limited or when available land is not legally accessible (e.g., Peluso, 1992). In the first situation, BoOTH (1985) and BoseruP
Corresponding author: Arief Darmawan

${ }^{*}$ Graduate School of Agricultural and Life Sciences, The University of Tokyo, 1-1-1 Yayoi, Bunkyo-ku, Tokyo 113-8657, Japan

${ }^{* 2}$ Department of Forest Resource Conservation and Ecotourism, Bogor Agricultural University, Bogor, P.O. Box 16002, Indonesia

\footnotetext{
${ }^{* 3}$ Present address

Faculty of Agriculture, Lampung University, Jln. Soemantri Brojonegoro No.1, Bandar Lampung 35145 , Indonesia
} 
(1965) reviewed the way agricultural production processes adjust over time to the increasing population pressure by looking at Javanese agricultural case studies. However, many cases of agricultural expansion in protected areas, notably those areas in high-density regions, are categorized under the latter situation (e.g., the cases of Sierra Madre Nature Park of the Philippines (Verburg et al., 2006) and Bangladesh (IFTeKhar and Hoque, 2005)). Peluso (1992) notes that millions of Javanese subsistence farmers live alongside statecontrolled forestlands in one of the world's most densely populated agricultural regions. Because their legal access and customary rights to the forest have been severely restricted and the legally available agricultural land is not sufficient, these subsistence farmers have been pushed toward illegal use of forest resources.

Indonesian Economic Crisis

Beginning in mid-1997, Indonesia experienced an economic crisis that collapsed almost all Indonesian economic sectors due to the extreme depreciation of its currency. Indonesian rupiah declined in value more than $70 \%$ from Rp. 2,450 to the US dollar in July 1997 , to Rp. 11,000 to the US dollar in mid-September 1998 (SundERLIN, 1999). The prices of essential commodities skyrocketed, and the numbers of people below the poverty line increased from $11 \%$ in 1996 to between 14 and 20\% in 1998 (PoPpele et al., 1999). Socioeconomic problems arose as a result, such as increased unemployment, rampant inflation, loss of consumer purchasing power, and grave social instability (SuNDERLIN et al., 2001; SunDERLIN, 1999). Law enforcement degenerated due to changes in the political situation following the economic crisis.

During this time of uncertainty, manufacturing industries collapsed and people looked to rural economic sectors such as agriculture that were comparatively sheltered from the effects of the crisis (e.g. Sunderuin, 1999). Furthermore, since the early days of the crisis, experts and policy-makers focused on agriculture as a means to escape the crisis. Faith in agriculture was justified and plantation farmers reacted by expanding their fields at the expense of forest cover.

\section{Objectives}

The objectives of this article are to examine the spatial pattern of agricultural expansion in a nature reserve area of the Banten Province, Indonesia, during $1994 \sim 2000$, and to characterize the situation of local people causing agricultural expansion in this area. The analysis was performed against the background of the economic crisis that occurred in 1997. These objectives were obtained by combining time-series of medium-spatial-resolution remote sensing analysis and information sourced from a socioeconomic household survey.

\section{MATERIALS AND METHODS}

Study Area

Our study was conducted in the Rawa Danau Nature Reserve. The area is located within the Cidanau Watershed, in the Serang District of the Banten Province, Indonesia, approximately $100 \mathrm{~km}$ west of Jakarta. Geographically, it is located at $6^{\circ} 10^{\prime}$ South and $106^{\circ} 00^{\prime}$ East (Fig. 1). The reserve was established in 1921 to conserve the last fresh water and peat swamp forest ecosystems that remained on Java Island, and to preserve the area's biodiversity (UNEP, 1999; VAN DER KAARS et al., 2001). It has a humid tropical climate with a dry season that lasts from April to October. According to the Ministry of Forestry, the area covers around 2,500ha. According to our calculations, based on the official boundary map, the reserve covers around 3,890 ha. This relatively flat area lies between $80-200 \mathrm{~m}$ of elevation and is surrounded by several hills. The Cidanau River flows through the center of the reserve. On the northern hill, adjacent to the nature reserve, there is an additional 1,700ha of protected forest called Gunung Tukung Gede. The water sourced from the Cidanau River supplies the Cilegon industrial complex and Cilegon City, both located in the northern coast (TsuYuKI and BABA, 2003).

The nature reserve and adjacent uplands are surrounded by densely settled agricultural and urban areas. There are six administrative sub-districts around the nature reserve: Cinangka, Padarincang, Ciomas, Anyar, Pabuaran and Mancak. At least eight villages (i.e. V1, V2, V3, V4, V5, V6, V7, and V8) are close to the nature reserve; the closest one (V1) forms a strip located on the border between the Rawa Danau Nature Reserve and the Gunung Tukung Gede Protected Forest. This village interacts directly with the nature reserve and is relatively isolated. Compared with V1, the other villages are quite distant from the Rawa Danau Nature Reserve boundary.

Materials

Our primary data sources were Geo-referenced Landsat Thematic Mapper (TM) images acquired on August 28, 1994, and July 19, 1997, and an Enhanced Thematic Mapper plus (ETM+) image acquired on April 14, 2000, of path 123/row 64 . These datasets were chosen because they were taken during the dry season and contained less than $10 \%$ cloud cover. A Rawa Danau Nature Reserve boundary map issued by the Ministry of Forestry, a map of the Cidanau Watershed boundary, and six sub-district boundary maps were collected and digitized. A ground truth survey was performed in 2001 to confirm land-use and land-cover in the study area (using a handheld GPS receiver and accompanying photographs). An explicit landmark indicating the nature reserve's boundary 


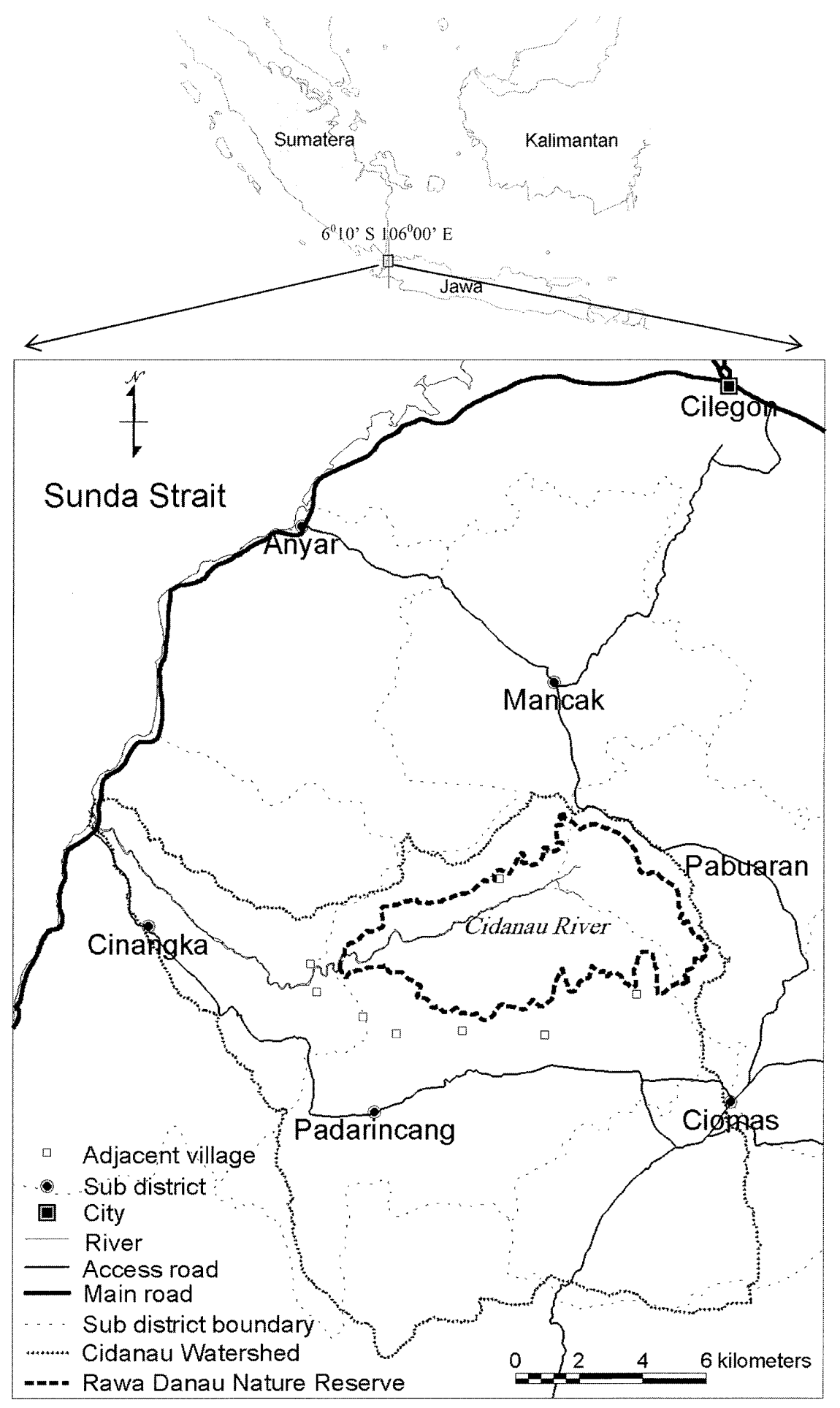

Fig. 1 Study area.

was noticed during this survey. We collected socioeconomic data while performing ground truth by interviewing household respondents living in the area surrounding the nature reserve.

J. For. Plann. 14:53-66(2009)
Flow of the Study

This study consisted of two interrelated efforts: first, a satellite-image analysis to establish the agricultural expansion of land-cover changes, and second, a household-survey 
analysis to understand the situation of local people that lies at the root of the agricultural expansion. First, to identify landcover changes during the two periods of interest, before and after the 1997 economic crisis, the Normalized Difference Vegetation Index (NDVI) differencing algorithm was employed. This algorithm was selected because of the inclusion of a vegetation feature that could function as a change indicator for the nature reserve, thereby indicating where vegetation had decreased, increased, or remained unchanged over observation periods. PHUA and TsuYukI (2004) described how to identify deforestation or agricultural expansion where a vegetation-decrease change has occurred. Thus to identify agricultural expansion as the major course of land-cover changes, time-series of agricultural land-cover derived from image classification were overlaid on the vegetation-decreased change. Second, a spatial analysis was then performed to recognize the spatial pattern of agricultural expansion with regard to the distance from the nearest villages and the nature reserve boundary. Finally, a descriptive qualitative analysis was performed on the socioeconomic household data obtained from the field survey.

Image Radiometric Correction

Relative radiometric normalization substantially reduces the inter-scene variability resulting from changes other than the land-cover changes (Elmore et al., 2000; MunYATI, 2000). We adopted the relative radiometric normalization based on pseudo-invariant features (ScHotT et al., 1988). The ETM+2000 dataset was chosen as the appropriate reference image for the relative radiometric normalization procedure because it is the most up-to-date dataset and has a wider range of ground truth sources. The so-called pseudo-invariant features (i.e., bare surface and calm water), the reflection of which, in theory, does not change over time, were carefully selected. Normalization equations were then derived from the regression analyses to adjust the spectral values of the timeseries image datasets to those of the ETM +2000 .

\section{Change Detection}

The most widely used NDVI was employed in an imagedifferencing algorithm for detecting change. NDVI operates on a special characteristic of the reflectance of vegetation in the near-infrared band $(N I R)$ and visible band $(R)$ of remote sensing data (LILLESAND et al., 2004). NDVI is defined as follows:

$$
N D V I=\frac{N I R-R}{N I R+R}
$$

The image differencing technique of NDVI was used to acquire information concerning changes in vegetation within the nature reserve over a period of time. The TM1997 dataset was used as the key point of observation in comparing

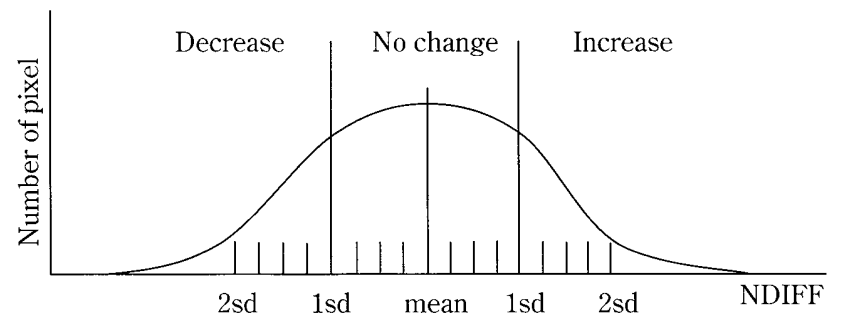

Fig. 2 Threshold determined using fractions of standard deviation from the mean to identify the vegetation decrease, vegetation increase, and vegetation unchanged in the NDVI differencing algorithm.

changes before and after Indonesia's economic crisis of 1997. NDVI differencing is calculated as follows:

$$
N D I F F=N D V I_{2}-N D V I_{1}
$$

where $N D I F F$ is the NDVI difference, $N D V I_{I}$ is the NDVI at the beginning of the observation period, and $N D V I_{2}$ is the NDVI at the end of the observation period.

Thresholding was applied to identify changes in vegetation over time including increases, decreases, and unchanged areas. There is no theoretical basis on how a threshold of change or no change can be established (PHuA and Tsuyuki, 2004). A standard deviation (sd) from the mean is often employed to establish a threshold, and is usually found suitable (JENSEN, 1996). In the present study, thresholds at 0.25 sd intervals were tested iteratively from $0.5 \mathrm{sd}$ to $2.0 \mathrm{sd}$ to obtain the highest accuracy (Fig. 2). Three test sites covered by change reference points (i.e., decrease, unchanged, and increase) derived from a visual image-to-image interpretation (TM1997 and ETM+2000) based upon observations made during ground truth were then selected. One of the sites was located at the northwestern part of the study area in the V1 locale. The remaining sites were in the V6 and V8 areas, in the southern part of the study area. The accuracy was assessed using an error matrix. Overall accuracy and Khat statistics were used to determine the most accurate threshold.

Image Classification and Agricultural Land-cover Extraction

The fundamental objective of image classification is to automatically categorize all the pixels within an image into land-cover classes or themes (Lillesand et al., 2004). Supervised classification is the procedure most often used for quantitative analysis of remote sensing image data (RICHARDS and JIA, 1999). In the present study, a supervised classification using a maximum likelihood classifier was performed on timeseries image datasets to obtain spatial information about the historical agricultural land-cover within the study area. Six bands were used, consisting of visible, near-infrared, and shortwave infrared bands (Bands 1, 2, 3, 4, 5 and 7) for each image dataset. From each image, two sets of sample regions were 
selected. One set, containing fifty sample regions, was used to represent pixels from each desired set of classes (i.e. shrub and bush, orchard, forest, dry field, inundated field, and "other"). The other set, also containing fifty sample regions with similar attributes, was used to assess accuracy (e.g., HILL, 1999). Each of the sample regions was developed using the ground truth, image visual interpretation, and the use of prior unsupervised classification results as land-cover references.

The "shrub and bush" category mainly consists of wetland grasses (Phragmytes karka) as well as other wetland shrubs and bushes. Forests in the nature reserve were dominated by swamp forest formations. The orchards were covered by relatively more scattered vegetation compared with the forests. Dry fields were dry agricultural fields (usually dry paddy fields) and inundated fields were waterlogged agricultural fields (usually wet paddy fields). The "other" category included both bare land and built-up areas, because the two categories had such a low percentage compared with the other classes. Now that we were interested in obtaining time-series agricultural land-cover, we categorized dry field and inundated field as "agriculture" and categorized other landcover classes as "non-agriculture".

\section{Spatial Analysis of Agricultural Expansion}

A spatial analysis was conducted by combining the timeseries agricultural land-cover, the artificial buffer areas generated from the mid-point of the eight villages nearest to the nature reserve, and the artificial buffer areas directing inward generated from the nature reserve boundary. We assumed that every household living near the nature reserve was equally likely to engage in encroachment activities.

The buffer areas were set at $0.1 \mathrm{~km}$ intervals, positioned 0.1 to $3 \mathrm{~km}$ from the center of the villages. Similar buffer intervals were applied inside the nature reserve, positioned from $0.1 \mathrm{~km}$ to $1.5 \mathrm{~km}$ from the reserve boundary. Matrices were then produced by overlaying these two buffer areas. To indicate any trends and spatial patterns relating to agricultural expansion with regard to the distances from the nearest villages and the nature reserve boundary, the ratio and the area of agricultural land-cover were calculated and charted for each buffer and each matrix, respectively.

\section{Household Data}

Data sourced from census and household surveys has been the most prevalent type of social data used in studies identifying the driving forces of LULCC (CAMPBELL et al., 2005). Individual household data allow for a better understanding of the land-use practices within each village, as most land-use decisions are made by individuals and households (CAMPBELL et al., 2005). We collected time-series population census data of the six sub-districts close to the study area from the local statistic office. The socioeconomic household data were obtained via interviews with the heads of households located near the nature reserve. Fifty-two respondents were chosen randomly from two villages. The nearest village (V1) is located directly adjacent to the nature reserve, while the second (V2) is located some distance away.

We required the respondents to answer questions concerning personal information, such as name, age, occupation, monthly income (i.e., farm income and off-farm income), education level, place of origin, the year the respondent came to live in their current home, and the number of people in their family. A figure of 500,000 Rp. was used as the baseline for a low-income household, based on the headcount-poverty line of Cilegon in 2001 (MUBYARTO, 2003). We also obtained information concerning the respondents' routines and their dealings with the nature reserve, as well as their knowledge and perceptions of the nature reserve. The last, data were collected on the respondents' land use, such as the extent of their land-holdings, type of land-use, land ownership, and land history.

Interviews with key informants who possessed particular knowledge concerning the various dimensions of land-use change issues in the study area were also conducted. The key informants provided additional information, particularly regarding the impact of external factors. The head of V1 and the authority of the Rawa Danau Nature Reserve were two of the key informants interviewed.

Most of the studies linking remote sensing observations and socioeconomic data have been performed using a direct relationship assessment by regression analysis at spatially selected units (e.g., at administrative units (SKOLE et al., 1994; WoOD and SKole, 1998), or at the village level (MerTens et al., 2000)). However, ENTWISLE et al. (1998) emphasized the difficulty of relating remotely sensed patterns of land-cover change with the field observations of land-use change, as people live in nucleated villages away from their fields. CAMPBELl et al. (2005) also pointed out that where common property resources exist, identification of the spatial correspondence between household characteristics and landuse decisions may be problematic.

In this study, to combine the agricultural expansion pattern data and the local socioeconomic situation we descriptively analyzed the household survey results rather than directly relating the remote-sensing results and the household survey data via regression analysis (e.g. CAMPBELL et al., 2005). Two classes of respondents were defined based on the distance between each village and the nature reserve. Frequency tables were constructed to descriptively analyze the dominant socioeconomic characteristics of each class of respondents. We then compared both classes to provide an insight into the differences between the respondents' socioeconomic characteristics and their roles in agricultural expansion. 


\section{RESULTS}

\section{Land-cover Change Detection}

Fig. 3 shows how the accuracy measures changed with different thresholds. In assessing the accuracy of the NDVI differencing algorithm, an $\mathrm{sd}=1$ threshold (e.g. -4.7 at the lowest and 7.8 at the highest thresholds of NDVI difference value in the 1994-1997 period) was determined to be the most suitable threshold for detecting changes of vegetation given $92.6 \%$ overall accuracy and $88.9 \%$ Khat statistic.

Based on the above result, the changes detected using the NDVI differencing algorithm for the period prior to the economic crisis (1994-1997) and that after the crisis (19972000) are shown in Fig. 4 and Table 1. The area under vegetation-decrease expanded nearly two times from 374ha (9.6\%) during the 1994-1997 period to 638ha (16.4\%) in the 19972000 period. These changes were detected in the southern and western parts of the nature reserve. The area under

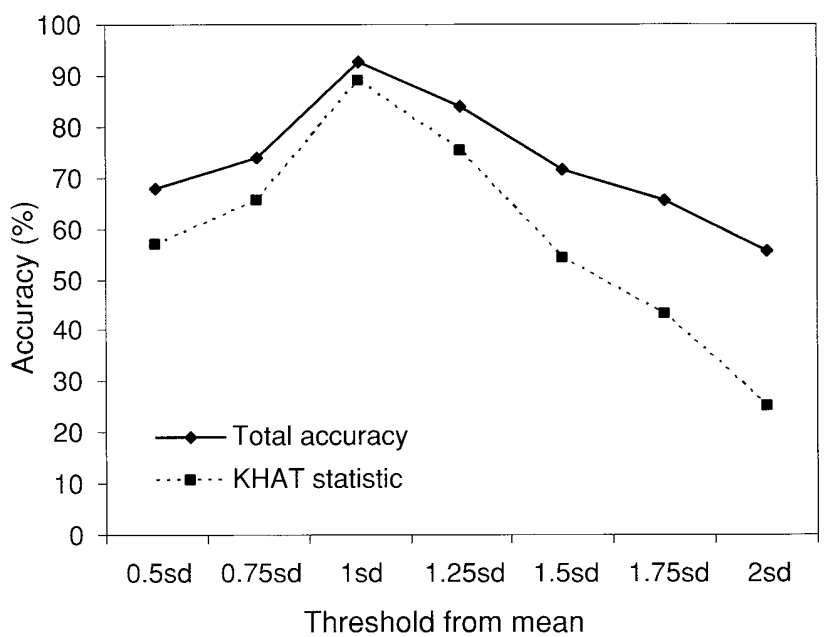

Fig. 3 Accuracy of the various threshold values. A threshold of one standard deviation from the mean gives the best change-detection accuracy.

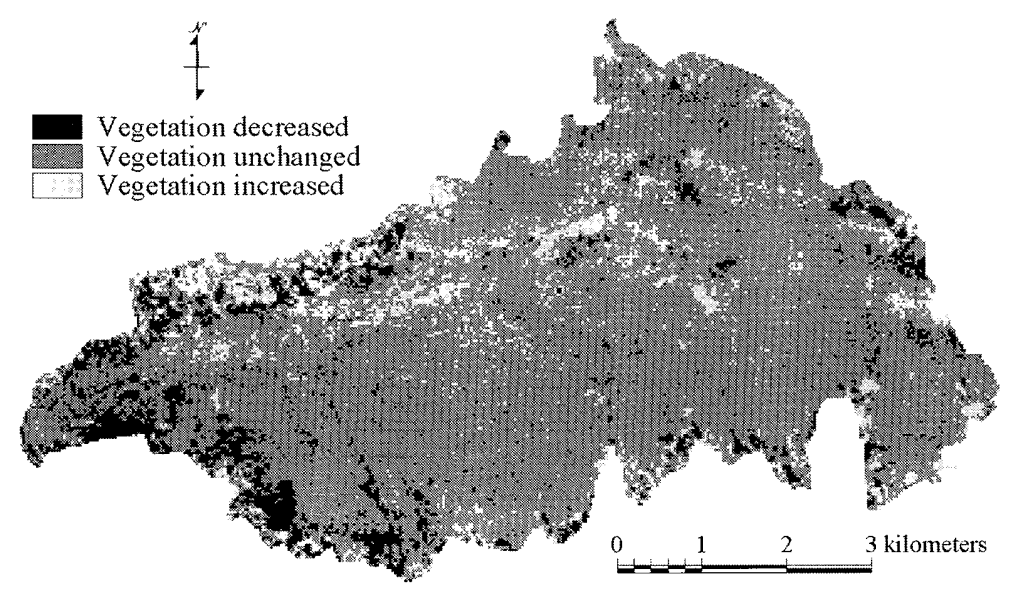

Before economic crisis (1994-1997)

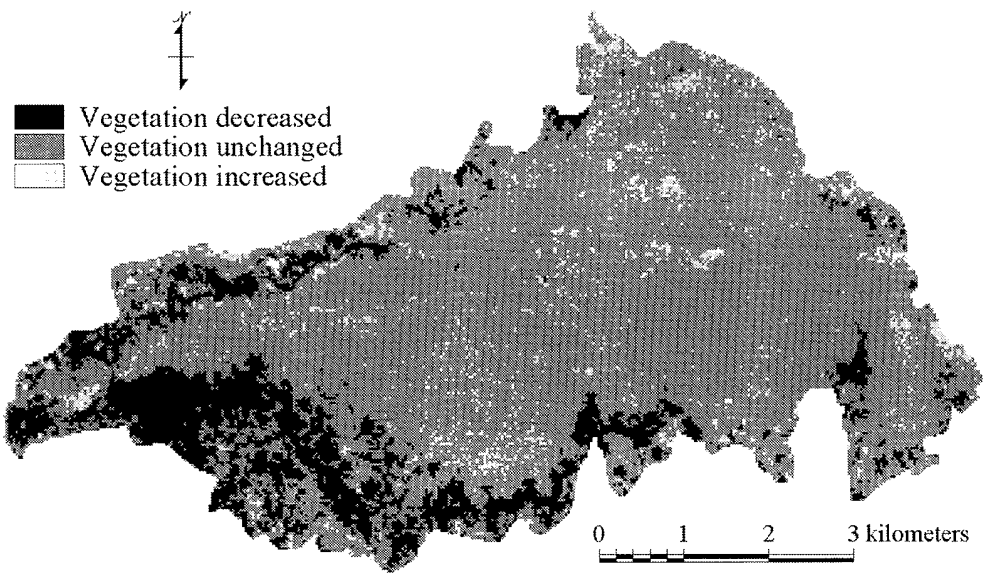

After economic crisis (1997-2000)

Fig. 4 Change detection results obtained using the NDVI differencing algorithm. 
Table 1 Change detection results using an NDVI differencing algorithm at a threshold of one standard deviation.

\begin{tabular}{|c|c|c|}
\hline \multirow[t]{2}{*}{ Change category } & $\begin{array}{c}\text { Before the economic crisis } \\
(1994-1997)\end{array}$ & $\begin{array}{l}\text { After the economic crisis } \\
(1997-2000)\end{array}$ \\
\hline & Area in ha & Area in ha \\
\hline Vegetation decrease & $374 \quad(9.6)$ & $638 \quad(16.4)$ \\
\hline Vegetation unchanged & $3,140 \quad(80.7)$ & $(78.6)$ \\
\hline Vegetation increase & $377 \quad(9.7)$ & $196 \quad(5.0)$ \\
\hline Total & $3,891 \quad(100.0)$ & $3,891 \quad(100.0)$ \\
\hline
\end{tabular}

Percentages are given in parentheses
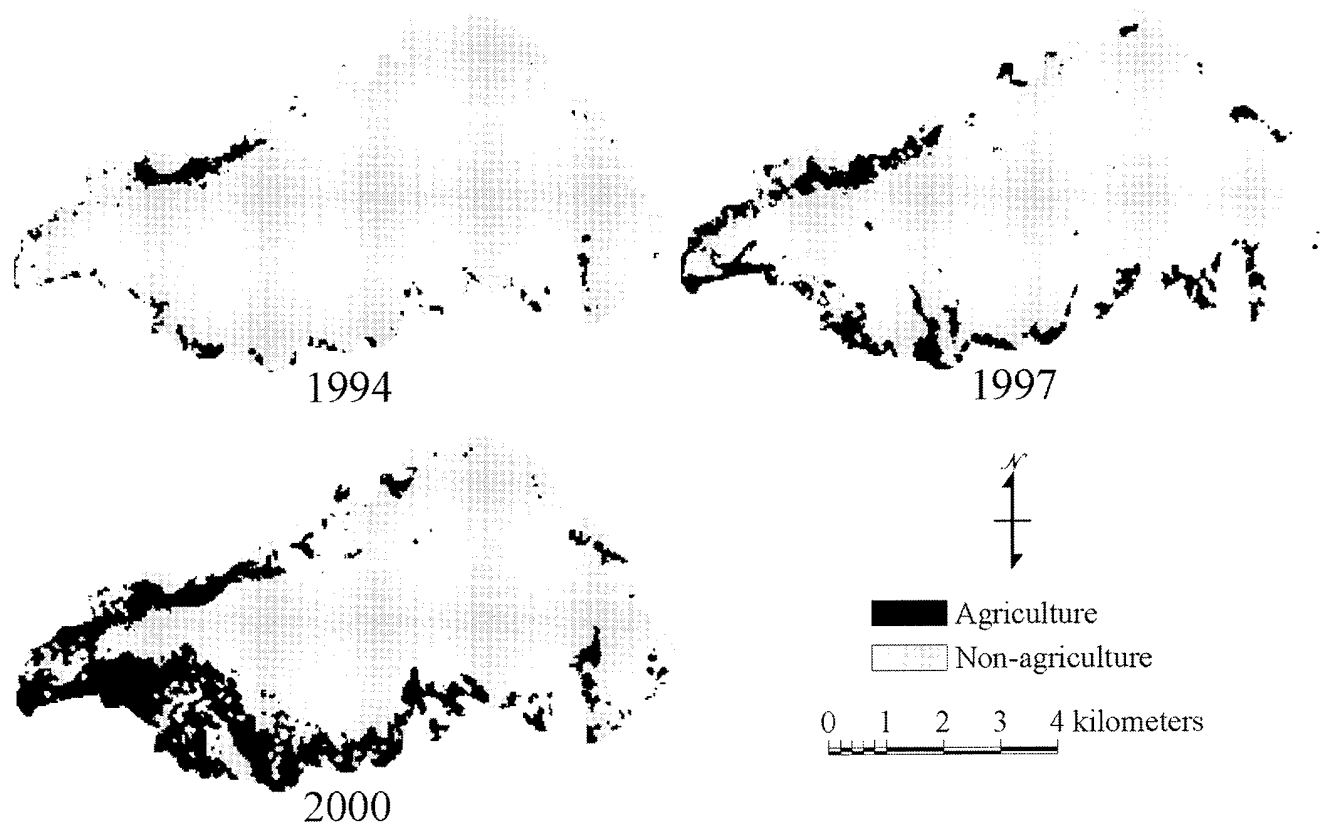

Fig. 5 Time-series spatial information of agricultural land-cover derived from supervised classification of satellite remote-sensing datasets.

unchanged-vegetation slightly decreased from 3,140 ha $(80.7 \%)$ in the $1994-1997$ period to 3,057 ha $(78.6 \%)$ during the 1997 2000 period. The area under vegetation-increase decreased from 377 ha $(9.7 \%)$ in the $1994-1997$ period to 196 ha $(5.0 \%)$ in the 1997-2000 period. Overall, the change-areas increased from 751 ha $(19.3 \%)$ in the $1994-1997$ period to 834 ha $(21.4 \%)$ in the 1997-2000 period.

Agricultural Expansion as the Major Course of Land-cover Changes

Historical agricultural land-cover maps derived from the supervised classification of time-series satellite imagery and its statistical results are described in Fig. 5 and Table 2, respectively. The overall accuracies of classification were above $90 \%$, with the exception of the 1997 data $(89 \%)$. The area
Table 2 Time-series area of land cover derived from supervised classification.

\begin{tabular}{|l|c|c|c|}
\hline $\begin{array}{c}\text { Year of } \\
\text { observation }\end{array}$ & $\begin{array}{c}\text { Non-agriculture } \\
\text { (ha) }\end{array}$ & $\begin{array}{c}\text { Agriculture } \\
\text { (ha) }\end{array}$ & $\begin{array}{c}\text { Total } \\
\text { (ha) }\end{array}$ \\
\hline 1994 & $3,730(95.9)$ & $161(4.1)$ & $3,891(100.0)$ \\
\hline 1997 & $3,488(89.7)$ & $403(10.3)$ & $3,891(100.0)$ \\
\hline 2000 & $3,038(78.1)$ & $853(21.9)$ & $3,891(100.0)$ \\
\hline
\end{tabular}

Percentages are given in parentheses

of agricultural land-cover had more than doubled from 276 ha in the 1994-1997 period to $623 \mathrm{ha}$ in the $1997-2000$ period. The results showed an obvious expansion of agricultural land-cover in the southern and western parts of the nature reserve, which were previously shrub and bush, or orchard. The expansion of 
Table 3 Land-cover changes in the areas under vegetation decrease and vegetation increase from 1994 to 1997.

\begin{tabular}{|c|c|c|c|c|c|c|}
\hline 1994 & \multicolumn{3}{|c|}{ Vegetation decrease (ha) } & \multicolumn{3}{|c|}{ Vegetation increase (ha) } \\
\hline 1997 & Non-agriculture & Agriculture & Total & Non-agriculture & Agriculture & Total \\
\hline Non-agriculture & $176 \quad(50.8)$ & $0 \quad(1.6)$ & 176 & $293 \quad(96.7)$ & $\begin{array}{ll}44 & (59.3) \\
\end{array}$ & 337 \\
\hline Agriculture & $170 \quad(49.2)$ & $28(98.4)$ & 198 & $10 \quad(3.2)$ & $30 \quad(40.5)$ & 40 \\
\hline Total & $346(100.0)$ & $28(\mathbf{1 0 0 . 0 )}$ & 374 & $303(100.0)$ & $74(100.0)$ & 377 \\
\hline
\end{tabular}

Percentages are given in parentheses

Table 4 Land-cover changes in the areas under vegetation decrease and vegetation increase from 1997 to 2000

\begin{tabular}{|c|c|c|c|c|c|c|}
\hline \multirow{2}{*}{1997} & \multicolumn{3}{|c|}{ Vegetation decrease (ha) } & \multicolumn{3}{|c|}{ Vegetation increase (ha) } \\
\hline & Non-agriculture & Agriculture & Total & Non-agriculture & Agriculture & Total \\
\hline Non-agriculture & $49 \quad(9.3)$ & $\begin{array}{ll} & (1.1) \\
\end{array}$ & 50 & $148 \quad(99.8)$ & $\begin{array}{ll}40 & (85.3) \\
\end{array}$ & 337 \\
\hline Agriculture & $479 \quad(90.7)$ & $109 \quad(98.9)$ & 588 & $\begin{array}{ll}0 & (0.2) \\
\end{array}$ & $7 \quad(14.7)$ & 40 \\
\hline Total & $346(100.0)$ & $110(100.0)$ & 638 & $148(100.0)$ & $47(100.0)$ & 377 \\
\hline
\end{tabular}

Percentages are given in parentheses

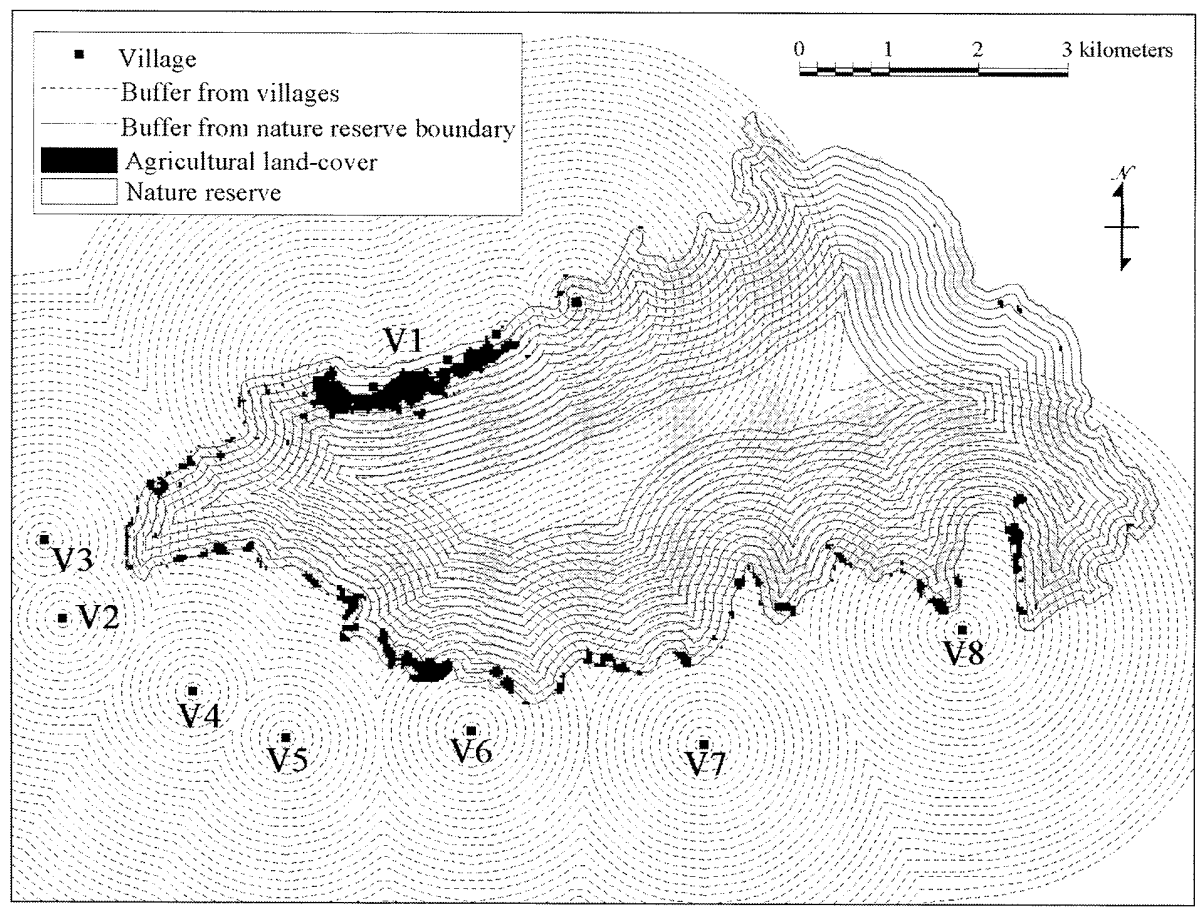

Fig. 6 Illustration of the procedures used for spatial analysis of agricultural expansion in 1994. The first buffer areas were established from the centers of the eight villages nearest to the nature reserve. The second buffer areas were directed inward, generated from the nature reserve boundary.

agricultural land-cover was also obvious on the northern edge of the nature reserve, where V1 lies adjacent to the nature reserve boundary.

Table 3 and Table 4 describe the results from the overlay analysis, which show the portion of agricultural expansion perceived as the major course of vegetation-decrease change. Our results for the 1994-1997 period show that $49.2 \%$ of the nonagricultural land-cover in 1994 had changed to agricultural land-cover by 1997. A rapid increase in agricultural land-cover was detected in the $1997-2000$ period, with $90.7 \%$ of the nonagricultural land-cover changing to agricultural land-cover.

Spatial Analysis of Agricultural Expansion

Fig. 6 illustrates the procedures used for the spatial analysis of agricultural expansion in 1994. Agricultural land- 
cover was observed to increase along the boundary of the nature reserve and then decreased moving away from the nature reserve boundary.

Over time, it was observed that agricultural expansion progressed across the boundary of the nature reserve (Fig. 7a). In the 1994-1997 period, agricultural land-cover grew by more than $10 \%$ only in the buffer areas located 0.1 to $0.3 \mathrm{~km}$ from the boundary of the nature reserve. Then, during the 1997-2000 period, a similar expansion occurred in the buffer areas located 0.2 to $1.3 \mathrm{~km}$ from the boundary of the nature reserve.

Agricultural land-cover was established in areas located further from the centers of villages (Fig. 7b). In the 1994-1997 period, agricultural land-cover grew more than $10 \%$ only in the buffer areas located between 0.4 and $1.3 \mathrm{~km}$ from the villages. However, during the 1997-2000 period, similar growth

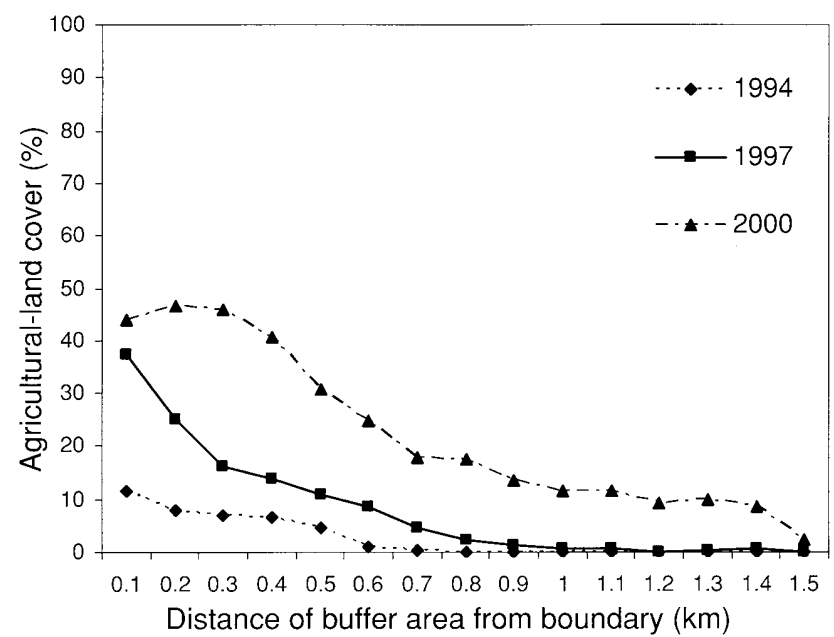

(a)

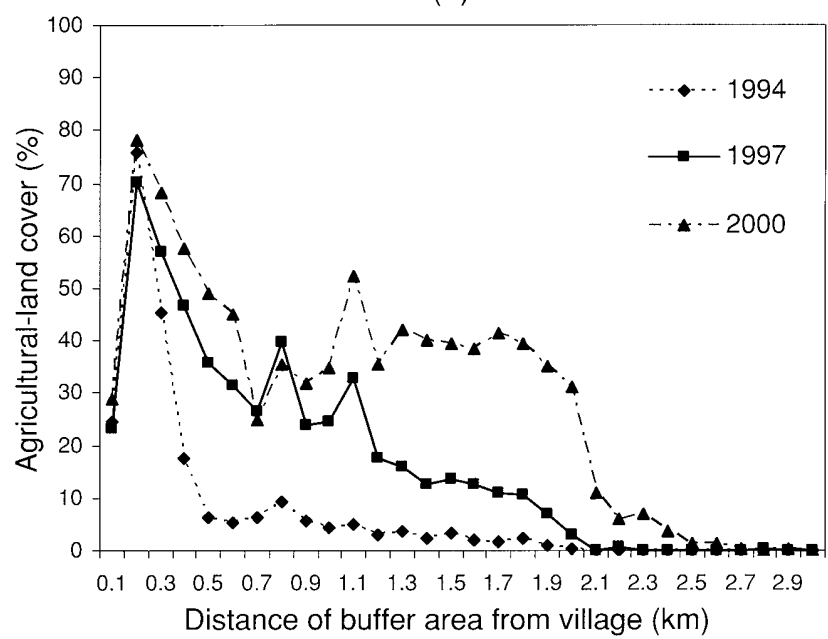

(b)

Fig. 7 Trend of agricultural expansion with regard to distance from the nature reserve boundary (a) and distance from the nearest villages (b). occurred further in the buffer areas located between 1.2 and $2.0 \mathrm{~km}$ from the villages.

Our time-series spatial pattern of agricultural expansion reveals that agricultural land-cover only slightly expanded at distances between 0.1 and $0.6 \mathrm{~km}$ from the villages and between 0.1 and $0.7 \mathrm{~km}$ from the nature reserve boundary (Fig. 8). This pattern indicates that the nearest villagers (V1) were unable to expand their agricultural land more than 0.7 $\mathrm{km}$ from the nature reserve's boundary due to the existence of swamp forest near to their village. This swamp forest remained undisturbed because of either the difficulty to convert or a prohibition to encroach enforced by the nature reserve authority.
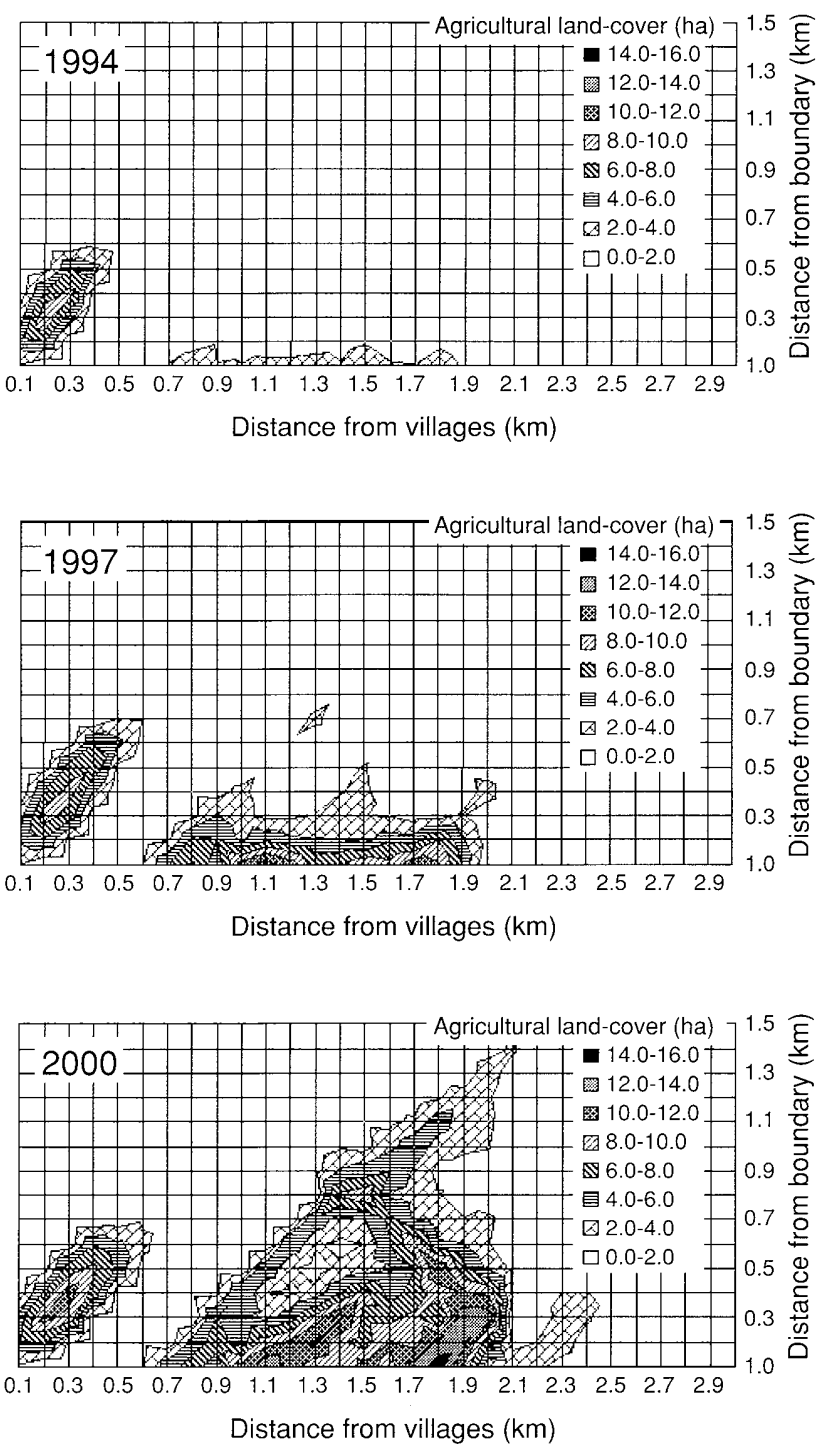

Fig. 8 Time-series spatial pattern of agricultural land-cover on matrices derived from overlying buffer areas from the nature reserve boundary and buffer areas from the centers of nearest villages. 
In contrast, there was a rapid expansion at distances between 0.6 and $2.4 \mathrm{~km}$ from the villages and between 0.1 and $1.3 \mathrm{~km}$ from the nature reserve boundary. The largest agricultural land-cover on matrices shifted from distances between 0.2 and $0.3 \mathrm{~km}$ from the villages in 1994 to $1.1 \mathrm{~km}$ in 1997 and $1.8 \mathrm{~km}$ in 2000 . This result indicates that not only the nearest village (V1), but also the more distant villages participated in agricultural expansion in the wetland grasses ecosystem in the southern and eastern parts of the nature reserve.
Socioeconomic Characteristics of the Local People Residing near the Nature Reserve

While most case studies failed to confirm the simplification of the role of population or poverty in causing tropical deforestation (LAMBIN et al, 2001), population growth and its pressure on land use have been central to thinking about the human-environment condition. The population census data for the six sub-districts surrounding the study area showed an increase in population growth from $2.5 \%$

Table 5 Socioeconomic characteristics of respondents

\begin{tabular}{|c|c|c|c|}
\hline \multirow[t]{2}{*}{ Characteristic } & \multirow[t]{2}{*}{ Criteria } & $\begin{array}{l}\text { Respondents from } \\
\text { the near village (V1) }\end{array}$ & $\begin{array}{l}\text { Respondents from } \\
\text { the far village(V2) }\end{array}$ \\
\hline & & Count $(\%)$ & Count $(\%)$ \\
\hline \multirow[t]{4}{*}{ Occupation } & Farmer & $15 \quad(88.2)$ & $34 \quad(97.1)$ \\
\hline & Trader & $1 \quad(5.9)$ & $\begin{array}{ll}0 & (0.0)\end{array}$ \\
\hline & Other & $1 \quad(5.9)$ & (2.9) \\
\hline & Total & $17(100.0)$ & $35(100.0)$ \\
\hline \multirow[t]{4}{*}{ Monthly income } & Less than Rp.500,000 & $12(70.6)$ & $31 \quad(88.6)$ \\
\hline & Rp.500,000-Rp.1,000,000 & $5 \quad(29.4)$ & $3 \quad(8.6)$ \\
\hline & Greater than Rp. $1,000,000$ & $\begin{array}{ll}0 & (0.0) \\
\end{array}$ & $1 \quad(2.9)$ \\
\hline & Total & $17(100.0)$ & $35(100.0)$ \\
\hline \multirow[t]{3}{*}{ Year of residence } & Before 1997 & $14 \quad(82.4)$ & $30 \quad(85.7)$ \\
\hline & After 1997 & $3(17.6)$ & $5 \quad(14.3)$ \\
\hline & Total & $17(100.0)$ & $35(100.0)$ \\
\hline \multirow[t]{4}{*}{ Place of origin } & Same district (Serang District) & $5 \quad(29.4)$ & $14 \quad(40.0)$ \\
\hline & Different district & $12(70.6)$ & $21 \quad(60.0)$ \\
\hline & Total & $17(100.0)$ & $35(100.0)$ \\
\hline & Less than or equal to $0.5 \mathrm{ha}$ & $8(50.0)$ & $28 \quad(80.0)$ \\
\hline \multirow[t]{3}{*}{ Land holding ${ }^{\mathbf{a}}$} & $0.5-1$ ha & $2(12.5)$ & $4 \quad(11.4)$ \\
\hline & Greater than or equal to 1 ha & $6 \quad(37.5)$ & $3 \quad(8.6)$ \\
\hline & Total & $16(100.0)$ & $35(100.0)$ \\
\hline \multirow[t]{5}{*}{ Education level } & Less than or equal to elementary graduation & $16(94.1)$ & $34 \quad(97.1)$ \\
\hline & Junior high graduation & $0 \quad(0.0)$ & $0 \quad(0.0)$ \\
\hline & Senior high graduation & $1 \quad(5.9)$ & $1 \quad(2.9)$ \\
\hline & Total & $17(100.0)$ & $35(100.0)$ \\
\hline & Paddy field & $12(75.0)$ & $33 \quad(94.3)$ \\
\hline \multirow[t]{4}{*}{ Land-use type $^{\mathrm{a}}$} & Orchard & $0 \quad(0.0)$ & $1 \quad(2.9)$ \\
\hline & Paddy field and orchard & $4 \quad(25.0)$ & $1 \quad(2.9)$ \\
\hline & Total & $16(100.0)$ & $35(100.0)$ \\
\hline & State land (nature reserve) & $10(62.5)$ & $17(48.6)$ \\
\hline \multirow[t]{6}{*}{ Land ownership ${ }^{a}$} & Private land & $2(12.5)$ & $1 \quad(2.9)$ \\
\hline & Land worker/rental & $0 \quad(0.0)$ & 17 (48.6) \\
\hline & State land and private land & $4 \quad(25.0)$ & $0 \quad(0.0)$ \\
\hline & Total & $16(100.0)$ & $35(100.0)$ \\
\hline & Inherited from parent including nature reserve land & $6(37.5)$ & $1 \quad(2.9)$ \\
\hline & Obtaining new land in the nature reserve & $6 \quad(37.5)$ & $16(45.7)$ \\
\hline \multirow[t]{5}{*}{ Land history ${ }^{\mathrm{a}}$} & Farm worker/rental & $0 \quad(0.0)$ & 17 (48.6) \\
\hline & Purchased land and obtained new land in the nature reserve & $0 \quad(0.0)$ & $0 \quad(0.0)$ \\
\hline & Inherited from parent and purchased land & $1 \quad(6.2)$ & $(0.0)$ \\
\hline & Inherited from parents and obtained new land in the nature reserve & $3(18.8)$ & $1 \quad(2.9)$ \\
\hline & Total & $16(100.0)$ & $35(100.0)$ \\
\hline
\end{tabular}

Percentages are given in parentheses

${ }^{\mathrm{a}}$ One respondent (a trader) from the V1 did not hold any agricultural land 
during the 1994-1997 period to $3.2 \%$ during the $1997-2000$ period. The census data also revealed an increase in the household-population growth, from 2.5\% during the 1994-1997 period to $4.9 \%$ during the $1997-2000$ period.

The socioeconomic characteristics of the households in V1 and V2 are described in Table 5. Farming was the main source of income for the households (more than $85 \%$ in both villages). Most of the farmers (more than $95 \%$ in both villages) grew rice. The majority of the households (more than $70 \%$ in both villages) received a low income. Although many of them were migrants $(70.6 \%$ from V1 and $60 \%$ from V2), most of the households arrived prior to the economic crisis (more than $82 \%$ in both villages). The level of education was low in both villages - only $5.9 \%$ and $2.9 \%$ of the households from V1 and V2 graduated beyond elementary school, respectively.

With regard to land ownership, $62.5 \%$ of the households in V1 cultivated in the nature reserve (state land), $12.5 \%$ of the households cultivated on private land, and another 25\% cultivated in both state and private lands. In V2, $48.6 \%$ of the households cultivated in the nature reserve, $2.9 \%$ cultivated on their own land, and the remaining $48.6 \%$ of the households cultivated within a yield-sharing-based leased property.

Based on historical land status, $37.5 \%$ of the households in V1 held inherited land, compared with just $2.9 \%$ of those in V2. It appeared that the people residing in the village adjacent to the nature reserve had farmed in the nature reserve for a long time. In contrast, while the households in V2 holdings of agricultural land in the nature reserve was a more recent occurrence, those households held more new land than those from V1 (45.7\% and 37.5\% of the respondents from V2 and V1, respectively).

The households' perception of the nature reserve indicated that they generally understood that the nature reserve was a protected area. However, most of them knew little about the Government's aims in protecting this area. Households only recognized that the nature reserve was protected against cutting down the trees. For this reason, and possible because of the difficulty of converting swamp forest into paddy fields, the swamp forests remained undisturbed. Only a minority of households stated that they used the nature reserve as a natural source of un-cultivated food, such as fish and vegetables. Most of the households knew that the water from Rawa Danau is used by a steel factory in Cilegon City. With this knowledge, the households requested a rewards system as a compromise among the needs of the local people, the factory's downstream water usage, and protection of the water catchments that feed Rawa Danau.

\section{Key Informants' Information}

Key informants confirmed that the encroachment area of the nature reserve, as of 2001 , had reached approximately 700 to $800 \mathrm{ha}$. The southwestern parts of the nature reserve experienced the highest levels of encroachment following several years of abandonment. There were settled areas in this region prior to 1988 , but the illegality of the settlements meant that in 1988 the Government moved the residents to an outer island via a transmigration project. However, the encroachment activity persisted after the completion of the project, and reached its peak after the 1997 economic crisis, when protection of the nature reserve was reduced as a result of political instability. Key informants stated that the majority of the encroachers were simply taking advantage of the uncertain political situation and resulting lack of forest policing, though the encroachers were aware that the area was a protected nature reserve. However, the key informants admitted that the increasing agricultural and livelihood costs derived from the economic crisis were the main reasons that encroachers were willing to take advantage of the lack of forest policing to encroach into the nature reserve.

\section{DISCUSSION}

\section{Operational Detection of Land-cover Change}

The NDVI differencing algorithm has been widely applied for monitoring land-cover change with varying degrees of success, for example tropical deforestation detection (PHUA and TSUYUKI, 2004), vegetation changes detection in semi-arid environment (ELMORE et al., 2000), and wetland change detection (MUNYATI, 2000). For all change detection applications, the most critical part is the placement of the threshold level. It should be noted that when placing the threshold level the type of change occurring should be predetermined to adequately place the threshold without excessive trial and error.

For agricultural expansion detection, it would be easier to determine the type of changes because agricultural expansion is related to a permanent conversion from natural landscape (e.g. forest, wetland grasses) to human induced landscape, which generally is represented by bare land or wet field. Although the analysis can be biased by the existence of green stage of paddy field, this bias could be reduced by selecting time-series data that fall within the minimum existence of green paddy field periods (e.g. at the middle of dry season (April) or the end of dry season (July and August)). Since the study area is a nature reserve that mostly consisted of green natural landscape, any vegetation changes, including those due to agricultural expansion activities, could easily be detected by the NDVI differencing algorithm. High level of accuracy achieved by the NDVI differencing algorithm indicated that the use of NDVI differencing algorithm to detect land-cover change that related to vegetation changes was appropriate.

During supervised classification, forests and orchards often misclassified each other, whereas the other classes were effectively separated. Forests and orchards contained significant biomass differences and these classes were 
separable by visual analysis. However, training areas were unable to distinguish these two classes precisely by digital analysis (supervised classification). Since we were interested in obtaining time-series agricultural land-cover, this misclassification was not an important problem. Merging classes into agriculture and non-agriculture had significantly increased classification accuracy.

Our analysis was strengthened by combining NDVI differencing and supervised classification within a hybrid method framework. In this approach, NDVI differencing algorithm was used to define the areas where supervised classification can be applied. The NDVI differencing method was performed to define the "decreased vegetation" where the post-classification method exposed the type of changes that might cause the decrease of vegetation (i.e. agriculture or nonagriculture). This combined approach effectively eliminates the identification of land-cover change in areas where no significant spectral change has occurred between the two dates of the images. Using a similar approach, YUAN et al. (1999) and PILON et al. (1988) reported that the hybrid approach satisfactorily enhances the results obtained by postclassification analysis by reducing errors of commission in North America's and Northwestern Nigeria's semi-arid environment, respectively. MERTENS and LAMBIN (2000) also reported that the hybrid approach reduces the misclassifications on the final land-cover change map by reducing the area for which the results of the post-classification method were retained.

\section{Land-cover Change and Agricultural Expansion}

LAMBIN and GEIST (2001) reviewed that land-cover change has long been viewed as being continuous, but, in fact, it is a disjointed process, with periods of rapid change, often triggered by a shock effect. Parallel to this view, our results demonstrate that the 1997 Indonesian economic crisis has played a major role in the way that land-use practices affected the protected areas. Our analyses of land-cover change revealed a sharp increase in the proportion of agricultural landcover during the period of the economic crisis. The combination of an NDVI differencing algorithm and supervised classification of time-series satellite remote-sensing data has effectively exposed the temporal pattern of land-cover changes and shown agricultural expansion to be the major course of such changes. The results showed that vegetationcover changes increased after the economic crisis (1997-2000) when compared with the period prior to the crisis (1994-1997). In particular, the area of vegetation-decrease expanded nearly two times from the 1994-1997 period to the 1997-2000 period. The change accredited to agricultural expansion doubled from one period to the next. Comparable to this situation, Cameroon's 1986 economic crisis led to a significant increase in forest clearing by forest villagers (MERTENS et al., 2000).

\section{Driving Forces of Agricultural Expansion}

The results of our spatial analysis indicate that nearby villagers are more likely to encroach on protected areas than more distant villagers. In addition, after a period of several years, even distant villagers will encroach on the nature reserve. This result is verified by the fact that the households of the viliage adjacent to the nature reserve tend to hold more agricultural land in the nature reserve than the ones from the more distant village. Aside from proximity of access, the household survey revealed that people in the more distant village possessed the other option for agricultural practices (e.g., holding agricultural land using a land-rent system) beyond encroaching on the nature reserve. Also, it should be noted that most of the households in more distant village held small agriculture lands. As a result, many of the households in the more distant village also encroached to the nature reserve for expanding their agricultural land especially after the economic crisis. Conversely, the people from the adjacent village had fewer options. Land tenure in the adjacent village was limited because the village was isolated, sandwiched between two neighboring protected areas. Because their legal access and customary rights to the forest have been severely restricted, these villagers have been pushed toward illegal use of forest resources (PELuSo, 1992).

Boserupian theory interprets the role of population growth in agricultural development in the context of broader conditions (LAMBIN et al., 2001). Our findings that population growth and agricultural expansion within the nature reserve were increasing during the economic crisis, in a complex role, also correspond with this theory. As the study area was surrounded by highly populated areas with limited land resources, the agricultural system developed from an extensive system into an intensive system (e.g. BooTH, 1985). However, the scarcity of land was combined with the existence of additional land that was not legally available for cultivation (i.e. the nature reserve). Considering this set of circumstances combined with the villagers' apathetic perception of the nature reserve, we conceive that the encroachments were inevitable. Our data shows that legal constraints would not be successful to inhibit agricultural expansion during a collapse of an economy combined with high population growth. IFTEKHAR and Hoque (2005) also emphasized that limited land availability and unemployment because of poor governance and depressed national economy on the background of population pressure and poverty have been identified as the major causes of forest encroachment in Bangladesh.

The condition during Indonesia's 1997 economic crisis was exacerbated an already existing encroachment situation. The encroachment on nature reserves during the crisis were influenced not only by the changed economic conditions, but also by the dramatically altered political conditions (SUNDERLIN et al, 2001). With the downfall of President Suharto's rule, many of the repressive aspects of his regime receded. One 
consequence of these events was that the restrictions on access to protected areas were relaxed. Agricultural expansion in the nature reserve was therefore motivated not just because of increased input costs, but also by un-monitored access to the land. Together with the increase in population growth and decline of the manufacturing industry during the economic crisis, such land-races became increasingly common.

\section{CONCLUSION}

In this study, we have demonstrated that agricultural expansion rapidly increased during the period after the economic crisis compared with the period prior to the crisis. By remote sensing analysis, the area under vegetationdecrease expanded nearly two times from the 1994-1997 period to the $1997-2000$ period. Under the area of vegetation-decrease, the portion of change accredited to agricultural expansion increased twice over those periods. By household survey and spatial analyses, it appears that initially the nearby villagers are more likely to encroach on protected areas than more distant villagers. However, after a period of several years, even distant villagers encroached on the nature reserve. Aside from proximity of access, the smaller size of agricultural land holdings, the larger number of tenant farmers and the increase of un-monitored access to the nature reserve after the economic crisis were the characteristics of agricultural expansion villages within the study area.

Considering the high tangible and intangible values of the Rawa Danau Nature Reserve, stakeholders in the area surrounding Rawa Danau need to remedy this situation, as a solution will not be reached by the local residents alone. For this reason, a proper solution must be carefully planned: one that recognizes the industrial demands downstream for the fresh water of the Cidanau River and needs of the local people upstream for a well-maintained environment.

\section{ACKNOWLEDGMENTS}

We would like to acknowledge the helpful advice, comments, and suggestions given by Dr.Deddy Maryadi, Dr.Jung Soo Lee, Mr.Tutut Sunarminto, Dr.Mustofa Agung Sarjono, and Dr.Mangala De Zoysa during the preparation of this manuscript. The authors also would like to acknowledge the helpful comments and suggestions from two anonymous reviewers on an earlier version of this manuscript. Part of this research was conducted under the JSPS - DGHE Core University Program in Applied Biosciences.

\section{LITERATURE CITED}

Booth, A., (1985): Accommodating a growing population in Javanese agriculture. Bull. Indonesian Econ. Stud. 21: 115-145

BOSERUP, E., (1965): The condition of agricultural growth: The economics of agrarian change under population pressure. George
Allen \& Unwin Ltd, London, 124pp

Campbell, D. J., Lusch, D. P., Smucker, T. A. and Wangui, E. E., (2005): Multiple methods in the study of driving forces of land-use and land-cover change: A case study of SE Kajiado district, Kenya. Hum. Ecol. 33: 763-794

Elmore, A. J., Mustard, J. F., Manning, S. J. and Lobell, D. B., (2000): Quantifying vegetation change in semiarid environments: Precision and accuracy of spectral mixture analysis and the Normalized Difference Vegetation Index. Remote Sens. Environ. 73, 87-102

Entwisle, B., Walsh, S. J., Rindfuss, R. R. and Chamratrithirong, A., (1998): Land use/land-cover and population dynamics, Nang Rong, Thailand. (In Liverman, D., Moran, E. F., Rindfuss, R. R. and STERN, P. C. (Eds.) People and pixels: Linking remote sensing and social science). National Academy Press, Washington DC, $256 \mathrm{pp}$

Fung, T., (1990): An assessment of TM imagery for land-cover change detection. IEEE Trans. Geo. Remote Sens. 28, 681-684

Geist, H. J. and Lambin, E. F., (2002): Proximate causes and underlying driving forces of tropical deforestation. BioScience 52, $143-150$

HILL, R. A., (1999): Image segmentation for humid tropical forest classification in Landsat TM data. Int. J. Remote Sens. 20, 10391044

IFTEKHAR, M. S. and Hoque, A. K. F., (2005): Causes of forest encroachment: An analysis of Bangladesh. GeoJournal 62, 95-106

JenSEN, J. R., (1996): Introductory digital image processing. PrenticeHall, Englewood Cliffs, New Jersey, 316pp

Kummer, D. M. and Turner II, B. L., (1994): The human causes of deforestation in Southeast Asia. BioScience 44, 323-328

LAMBIN, E. F. and GeIST, H. J., (2001): Global land-use and land-cover change: What have we learned so far? Global Change News. 46, 27-30

Lambin, E. F., Turner, B. L., Geist, H.J., et al., (2001): The causes of land-use and land-cover change: Moving beyond the myths. Global Environ. Change 11, 261-269

Lillesand, T. M., Kiefer, R. W. and Chipman, J. W., (2004): Remote sensing and image interpretation. John Wiley \& Sons, Inc, 763pp

Mertens, B. and Lambin, E. F., (2000): Land-cover-change trajectories in Southern Cameroon. Ann. Assoc. Am. Geog. 90, 467-494

Mertens, B., Sunderlin, W. D., Ndoye, O. and Lambin, E. F., (2000): Impact of macroeconomic change on deforestation in South Cameroon: Integration of household and remotely-sensed data. World Development 28, 983-999

MUBYARTO., (2003): Menanggulangi kemiskinan di Kota Cilegon. J. Ekonomi Rakyat Th II, 8 (in Indonesian)

MunYaTI, C., (2000): Wetland change detection on the Kafue Flats, Zambia, by classification of a multi-temporal remote sensing image dataset. Int. J. Remote Sens. 21, 1787-1806

Peluso, N. L., (1992): Rich forest, poor people: Resource control and resistance in Java. Berkeley: The University of California Press, $321 \mathrm{pp}$

PhuA, M. H. and TsuyukI, S., (2004): Deforestation detection in Kinabalu Area, Sabah, Malaysia by using multi-sensor remote sensing approach. J. For. Plann. 10, 31-40

Pilon, P. G., Howarth, P. J. and Bullock, R. A., (1988): An enhanced 
classification approach to change detection in semi-arid environments. Photogramm. Eng. Remote Sens. 54, 1709-1716

Poppele, J., Sumarto, S. and Pritchetr, L., (1999): Social impacts of the Indonesian economic crisis: new data and policy implications. SMERU (Social Monitoring and Early Response Unit), Jakarta, $35 \mathrm{pp}$

RICHARDS, J. A. and JiA, X., (1999): Remote sensing digital image analysis: An introduction. Springer-Verlag, Berlin Heidelberg, 363pp

Schott, J., Salvaggro, C. and Volchok, W., (1988): Radiometric scene normalization using pseudoinvariant features. Remote Sens. Environ 26, 1-16

SingH, A., (1989): Digital change detection techniques using remotely-sensed data. Int. J. Remote Sens. 10, 989-1003

Skole, D. L., Chomentowsky, W. H., Salas, W. A. and Nobre, A. D., (1994): Physical and human dimension of deforestation in Amazonia. BioScience 44, 314-322

Sunderlin, W. D., (1999): Between danger and opportunity: Indonesia and forests in an era of economic crisis and political change. Society \& Natural Res. 12, 559-570

Sunderlin, W. D., Angeisen, A., Resosudarmo, D. P. and Dermawan, A., (2001): Economic crisis, small farmer well-being, and forest cover change in Indonesia. World Development 29, 767-782

TsuYuKI, S. and BABA, A., (2003): Detecting land-use change using remote sensing in Cidanau Watershed, Indonesia. (In Hayashi, Y., Manuwoto, S. and Hartono, S. (Eds.) Sustainable agriculture in rural Indonesia). Gadjah Mada University Press, Yogyakarta, $468 \mathrm{pp}$
UNEP., (1999): Technology needs for lake management in Indonesia: investigation of Rawa Danau and Rawa Pening, Java. Newsletter and Technical Publications, http://www.unep.or.jp/ietc /publications/TechPublications/TechPub-9/9danB.asp

Van der Kaars, S., Penny, D., Tibby, J., Fluin, J., Dam, R. A. C. and SUPARAN, P., (2001): Late quarternary palaeoecology, palynology and palaeolimnology of a tropical lowland swamp: Rawa Danau, West-Java, Indonesia. Palaeogeography, Palaeoclimatology, Palaeoecology 171, 185-212

Verburg, P. H., Overmars, K. P., Huigen, M. G. A., De Groot, W. T. and VeldKamp, A., (2006): Analysis of the effects of land-use change on protected areas in the Philippines. Applied Geography 26, 153-173.

WALKER, R. and Homma, A., (1996): Land-use and land-cover dynamics in the Brazillian Amazon: An overview. Ecol. Econ. 18, $67-80$

Wood, C. H. and Skole, D., (1998): Linking satellite, census, and survey data to study deforestation in the Brazillian Amazon. (In Liverman, D., Moran, E. F., Rindfuss, R. R. and Stern, P. C. (Eds.) People and pixels: Linking remote sensing and social science). National Academy Press, Washington DC, 256pp

Yuan, D., Elvidge, C. D. and Lunetta, R. S., (1999): Survey of multispectral methods for land-cover change analysis. (In Lunetta, R. S. and Elvidge, C. D. (Eds.) Remote sensing change detection: Environmental monitoring methods and application. Taylor and Francis Ltd, London, 318pp 